\title{
Effect of Enzyme Addition in the Making of Pedro Ximenez Sweet Wines Using Dynamic Pre-fermentative Maceration
}

\author{
F. Espejo*, S. Armada \\ Quality Department, Navisa Industrial Vinícola Española S.A. Ctra. de Montalbán s/n, 14550 Montilla, Córdoba, Spain \\ Date submitted for publication: March 2010 \\ Date accepted for publication: July 2010 \\ Key words: Sweet wines, Pedro Ximenez, pectolytic enzymes, dynamic maceration, pre-fermentative operations
}

\begin{abstract}
This work evaluated the effect of two commercial pectolytic enzymes on some oenological parameters before and after enzymatic treatments with pre-fermentative dynamic maceration at room temperature for three hours. The study was conducted on an industrial scale using musts from sun-dried grapes of the Pedro Ximenez variety. Statistical analysis and sensory rating showed that the resulting wines varied significantly in total soluble solids ( ${ }^{\circ}$ Brix) and in the final sensorial controls. On the other hand, the enzyme treatment had no effect on the content of total polyphenols (TPI) and other chemical characteristics of the obtained musts. A higher qualitative level was observed with regard to aroma and gustative quality compared to the control. The results also demonstrate that total juice yield improved after enzyme addition together with dynamic maceration.
\end{abstract}

\section{INTRODUCTION}

Commercially available enzymes have been widely used in the oenological industry in wine- producing countries to improve important characteristics of wines, such as aroma and colour. Furthermore, enzymes are used extensively in the fruit-processing industry and other food sectors (Kashyap et al., 2001). The use of pectolytic enzymes has been shown to be suitable to improve the extraction of colour in red wines (Revilla \& González-San José, 2003; Bautista-Ortín et al., 2005), aroma compounds (CanalLlauberes, 1990; Castro-Vázquez et al., 2002; Cabaroglu et al., 2003) and soluble polysaccharides (Ayestarán et al., 2004; Doco et al., 2007) from the skins and pulp of the grapes. Enzymes may be used to increase the grape must yield during pressing, facilitate the settling of musts, and improve clarification and filtration. Numerous papers have been published on the use of enzymes in the production of white, red and rosé wines (Cruess et al., 1951; Ducruet et al., 1997; Pardo et al., 1999; Salinas et al., 2003). Studies on the use of enzymes in sweet wines are relatively limited in comparison to those performed on white and red wines.

The principal enzyme groups used in winemaking are pectinase, cellulose, hemicellulase, oxidoreductase, protease and $\beta$-glycosidase. Evidently, the enzymatic preparations and their principal and secondary activities are key factors in the results obtained in the products (Pimenta-Braz et al., 1998; Guérin et al., 2009). Enzymes in wine production is controlled by Commission Regulation EC 606/09, 2009). The general use of enzymes is regulated by the European Union according to Commission Regulations No. 1331 and 1332 (2008). Recently, the International Organisation of Vine and Wine revised a monograph on enzymatic preparations applied to grapes and their derivatives (OIV, 2009).

Enzyme use in must treatments is related to skin maceration as an additional and complementary process. Skin contact or maceration has been used to increase the aroma in white varietal wines through the extraction of aromatic compounds and nonvolatile sugar-bound glycosidic conjugates (Selli et al., 2003), since aroma precursors are located mainly in the grape skin (Mateo \& Jimenez, 2000; Ganga et al., 2001; Sánchez Palomo et al., 2006). The skin contact technique also produces an extraction of phenolic components from grape solids in white and red wines (Hernanz et al., 2007) and is the most important process that characterises the elaboration of rosé and red wines. Phenolic compounds from grapes and wines are receiving increasing interest because of diverse health benefits attributed to them (Moreno et al., 2007; Parker et al., 2007; Katalinić et al., 2010).

Pedro Ximenez varietal sweet wines are produced almost exclusively in the Montilla-Moriles Designation of Origin in the south of the province of Cordoba, Spain. It is a region situated close to the Guadalquivir River valley, where average diurnal temperatures in the summer can rise above $40^{\circ} \mathrm{C}$ and with ambient humidity values of between $30 \%$ and $40 \%$. The grapes are carefully hand-picked and spread out on straw mats or on bands of plastic material over a cleared area. Wine production begins with the natural dehydration of the grape bunches by direct exposure to sunlight for about five to 10 days to become raisins, with constant turning-over of the bunches at the optimum degree of maturity. In the traditional Pedro Ximenez process and depending on available equipment, the extraction of must is performed with horizontal presses, but a second step is usually necessary to improve juice yield from the mash and, as a result, high pressure has to be applied using hydraulic presses. The dark must obtained has a high sugar content because of water evaporation from the grapes, producing a very low yield $(\sim 29 \%$, w/v, of must). This may vary from year to year. Once the must has been collected, ethanol is added to prevent the start of alcoholic fermentation. After the stabilisation and maturation period, the sweet wine is aged in oak 
casks by the traditional criaderas and soleras system, using only the oxidative method.

The sun-drying process develops new aromatic compounds such as ethyl acetate, acetoin, $\gamma$-butyrolactone, benzyl alcohol, isobutanol, 2-phenylethanol and isoamyl alcohols through anaerobic metabolism (Franco et al., 2004; Márquez et al., 2008) or 2-furaldehyde and 5-methyl-2-furaldehyde by the Maillard reactions of sugars. The wine quality is greatly influenced by aroma and flavour compounds, which come from the grapes, the sun-drying process or from later during wine ageing, because no fermentation is carried out in these traditional sweet wines. Therefore, it is important to take full advantage of the development of aromas and to increase aroma compounds during winemaking of these sweet wines, particularly in the light of the fact that Pedro Ximenez is consider a neutral aromatic variety. Consequently, it is necessary to carefully select commercially available pectolytic enzymes and to know their effect on each grape variety, which may have a different composition according to the specific winemaking conditions applied. In this regard, pre-fermentative dynamic and rapid maceration was used with enzyme addition to enhance the aroma and polyphenol contents in the musts obtained, while improving the pressability of the sun-dried grape mash.

The principal objective of this research was to evaluate, on an industrial scale, the influence standard analytical parameters have on two commercial pectolytic enzymes, compared to a nonenzyme-treated control during novel pre-fermentation dynamic maceration of sun-dried Pedro Ximenez grapes. The sweet wines obtained were characterised by means of chemical analyses and sensorial comparison. Furthermore, this work could contribute to an oenological interest in modifying the traditional winemaking process to improve the quality of these sweet wines.

\section{MATERIALS AND METHODS}

\section{Grape samples}

The experimental trials were conducted with healthy grapes from Vitis vinifera L. cv. Pedro Ximenez, a white variety, all from the same vineyard situated in the Montilla-Moriles region (Andalucia, Spain). The grapes, harvested manually, were transported in $20 \mathrm{~kg}$ plastic boxes to the sun-drying area. The main analytical parameters controlled on reception of the sun-dried grape samples were the $\mathrm{pH}$ values (from 4.10 to 4.24 ) and ${ }^{\circ}$ Brix (from 43 to 51.8). The lot samples of the sun-dried grapes were divided randomly into three categories (control, enzyme VV and enzyme EM) in the winery. Four different, representative replicates of each type were processed on an industrial scale during one harvest period.

\section{Enzymes used}

Two commercial preparations in granular form were used in the experiments. Both enzymes were purified of cinnamyl esterase activity and did not contain genetically modified organisms. The enzymes were diluted in 1:10 parts of distilled water. The dosage tested ( $2 \mathrm{~g}$ per $100 \mathrm{~kg}$ of sun-dried grapes) was recommended by the manufacturers. Additional experiments were carried out with an alternative dose at 3 and $4 \mathrm{~g}$ per $100 \mathrm{~kg}$ of sun-dried grapes.

Vinozym ${ }^{\circledR}$ Vintage FCE (VV) from Novozymes A/S (Bagsvaerd, Denmark) is indicated for the extraction of phenolic and aromatic compounds and has an enzymatic activity of $5000 \mathrm{FDU} / \mathrm{g}$ at $20^{\circ} \mathrm{C}$, and contains mainly polygalacturonase activity. This preparation is obtained from Aspergillus niger and A. aculeatus.

Endozym ${ }^{\circledR}$ Muscat (EM) from Pascal Biotech (Paris, France) has an enzymatic activity of $12500 \mathrm{FDU} / \mathrm{g}$ at $20^{\circ} \mathrm{C}$. This enzyme is obtained from $A$. niger and formulated for use in aromatic grape varieties and musts that are difficult to clarify. The preparation contains pectinase (pectinesterase and polygalacturonase), but has other secondary activities such as cellulose and hemicelullase. The following data about its enzymatic activities was supplied by the manufacturer: cellulase (70 units $\mathrm{CMC} / \mathrm{g}$ ), polygalacturonase (4 450 units $\mathrm{PG} / \mathrm{g}$ ), pectinesterase (650 units $\mathrm{PE} / \mathrm{g}$ ) and pectinlyase (10 000 units PL/g).

\section{Reagents}

The main reagents used for the analysis were hydrochloric acid $37 \%$, anhydrous sodium carbonate, potassium thiocyanate and sodium hydroxide from Scharlau (Barcelona, Spain). The formaldehyde 37-38\% w/w and Folin-Ciocalteu reagent were from Panreac (Barcelona, Spain). The gallic acid came from Fluka (Sigma-Aldrich, Madrid, Spain). All the reagents used were of analytical grade or better.

\section{Experiments}

The skins and pulp of crushed but non-destemmed grapes were macerated in their own juice prior to pressing. The enzyme solution was dosed directly during the grape mash and homogenised in the rotating macerator to achieve the correct distribution. A schematic diagram of the process followed is shown in Fig. 1. Dynamic skin maceration was carried out for $3 \mathrm{~h}$ in a closed stainless steel macerator tank with about $3000 \mathrm{~kg}$ per tank at room temperature. An automatic cycle was followed for the maceration, according to which the tank turns to each side a number of times, and the time in motion was $88 \mathrm{~min}$ ( $49 \%$ of the total period). The temperature of the grape mash was checked before and after the cycle and remained between 28 and $36^{\circ} \mathrm{C}$ during all experiments. There were no indications of intracellular fermentation during and after the maceration process. The time of maceration and enzyme dosage were previously optimised in laboratory trials. Sulphur dioxide was not added in the maceration trials. Control experiments were treated in the same way except for the enzyme addition. The grape mash was then pressed in horizontal pneumatic presses.

The must samples (mixture of two aliquots from the bottom and upper zone of the tank) were collected in the following phases of the experiment: Sample A once the macerator had been filled, before enzyme addition, and sample B after the dynamic maceration process with the enzyme action. The must samples were taken and analysed immediately. After analysis, these must samples were fortified with ethanol up to $9 \% \mathrm{v} / \mathrm{v}$, and cooled in a refrigerator at $6^{\circ} \mathrm{C}$ for approximately $24 \mathrm{~h}$ to produce a static sedimentation of solids. The sweet wines obtained were then separated from the precipitated solids and subjected to the final analyses. All the wines were stored in black glass bottles in the dark at $15 \pm 3^{\circ} \mathrm{C}$ until the sensory trials.

\section{Physicochemical determinations \\ Residual total soluble solids}

The residual Brix degree of the grape pomace (skin, seeds, pulp and stems) was obtained by weighing a sample of press-leached pomace after pressing in horizontal pneumatic presses. Thus, four randomly sampled aliquots of $125 \mathrm{~g}$ were taken and these 


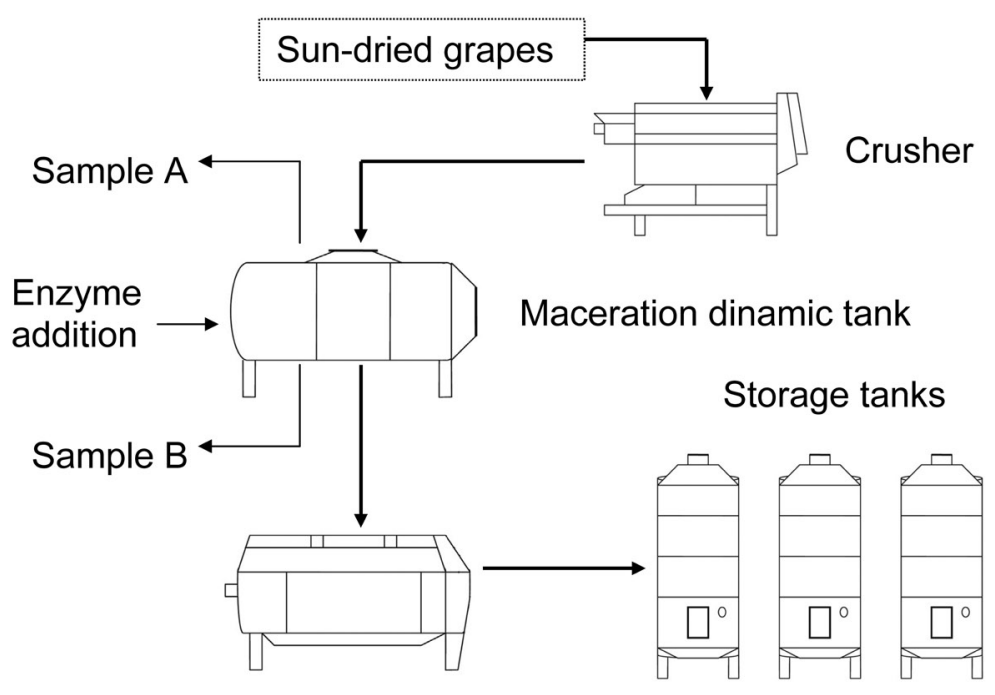

Pneumatic press

FIGURE 1

General flow scheme of the production process of Pedro Ximenez sweet wine in the experiments conducted on industrial scale.

amounts were combined into a composite sample (500 g) for each experiment. Following this, the pomace sample was submerged in distilled water $(1 \mathrm{~L})$ and $1 \mathrm{~g}$ of potassium metabisulphite was added. The mixture was then macerated for $72 \mathrm{~h}$ in a refrigerator at $5^{\circ} \mathrm{C}$; this mash was filtered through filter paper of $200 \mathrm{~mm}$ in diameter (Filter-Lab, Barcelona, Spain) and the clear liquid was measured as ${ }^{\circ}$ Brix by refractometry with a digital refractometer model PR-201 $\alpha$ at $20^{\circ} \mathrm{C}$ (Atago \& Co, Kyoto, Japan).

\section{Oenological determinations}

The total soluble solids (TSS) of the must were measured as ${ }^{\circ} \mathrm{Brix}$ using the refractometer previously described. Titratable acidity (TA) and $\mathrm{pH}$ values were measured by potentiometric titration up to $\mathrm{pH}=7$ with Titromatic $2 \mathrm{~S}$ (Crison Instruments, Alella, Spain). The easily assimilable nitrogen content (EAN) was analysed following the method described by Giannessi and Matta (1978), based on the blockage of the aminic function of the amino acids with formaldehyde and acidimetric titration with a potentiometer micro-pH 2002 (Crison Instruments, Alella, Spain). The total polyphenols were determined according to a spectrophotometric method with the Folin-Ciocalteu reagent in alkaline medium (Singleton \& Rossi, 1965) using a spectrophotometer UV-1800 (Shimadzu, Kyoto, Japan). A calibration curve was constructed with solutions of gallic acid of known concentration. The total polyphenol index (TPI) is the absorption at $280 \mathrm{~nm}$ by direct measurement of the diluted sample at 1:100 with distilled water, using quartz cells of $10 \mathrm{~mm}$ path length (Ribéreau-Gayon et al., 2006). Determination of turbidity was performed by the measurement of absorbance at $620 \mathrm{~nm}$. The usual remaining analyses (volatile acidity, reducing sugars, alcoholic strength and iron) were carried out according to the official methods of the European Community (Commission Regulation, 1990). All analyses were done in triplicate and the results were expressed as mean values.

\section{Sensorial analysis}

A comparative discrimination sensorial analysis was performed by a triangle test series (ISO, 2004) and by descriptive sensorial tests (Stone \& Sidel, 2004) after four months of maturation. In order to quantify the differences, aroma (quality and intensity), flavour (quality and intensity), astringency and herbaceous notes were evaluated, as well as the final sensorial equilibrium to obtain a preferential organisation among the samples. A panel of ten expert wine tasters who were familiar with this type of sweet wine carried out the trials after specific training about the study. The key attributes for this sweet wine had been identified previously, when it is young, to define the quality degrees and criteria to score each parameter. For the discrimination and descriptive tests, two and three replicates respectively were carried out at different times. Sensory trials were performed at $22 \pm 1^{\circ} \mathrm{C}$ in a laboratory room with independent cabins. Samples were numbered with three digits and randomly presented to avoid bias due to the order of presentation. Qualitative references for astringency and herbaceous defects were prepared with a Pedro Ximenez sample as base sweet wine by adding $4 \mathrm{~g} / \mathrm{L}$ of commercial tannin (AEB Ibérica, Barcelona, Spain) for astringency and $0.05 \mathrm{~mL} / \mathrm{L}$ of cis3-hexen-1-ol (Sigma-Aldrich, Madrid, Spain) for herbaceous excess. A point scale, based on the score sheet of the international wine competition of the OIV (1994), was chosen for scoring the parameters to be evaluated. Appearance attributes (colour intensity, hue or cloudiness) were not evaluated as the samples were not considered to be finished sweet wines.

\section{Statistical methods}

The statistical tests performed were analysis of variance (one-way ANOVA) of the effect of enzymes on the parameters analysed expressed as differential variation in percentage for the musts. The variation index was defined as the relative difference of the studied parameter according to the equation:

$\Delta$ parameter $(\%)=\left[\left(I-I_{0}\right) / I_{0} \times 100\right]$,

where $I_{0}$ and $I$ are the values before (sample A) and after enzymatic treatment with dynamic maceration (sample B) respectively. At the same time, a Tukey HSD test at the 5\% significance level $(P<$ $0.05)$ was used to separate the means. Multivariate methods were 
used to study the results of the sensory analyses. All the statistical tests were done using the software package SPSS ${ }^{\circledR}$ (version 12 for Windows; SPSS Inc., Chicago, USA), and PanelCheck V1.3.2 software (http://www.panelcheck.com) was also used for the sensory analyses.

\section{RESULTS AND DISCUSSION}

\section{Effect of enzymes on must parameters}

The optimised conditions for enzymatic maceration were applied on an industrial plant scale. The variation in some oenological parameters was studied before and after treatments in these very sweet musts according to the process shown in Fig. 1. The extraction of the must compounds from the grapes into the must is mainly a diffusion process. Thus, the joint action of the enzymes and dynamic maceration helps the better extraction of desirable compounds from the grape mash. The enzymes acted on the skins, stems and the must. The results of the parameter changes in the enzyme-treated and control musts are shown in Table 1. In general, the chemical parameters of the musts produced from enzymatically macerated grapes were very similar to those of the musts from grapes in which maceration took place without enzymes.

Contrary to what was expected, the differential values for the TPI showed similar patterns in all the experiments. The enzyme preparations did not affect the polyphenol contents of the samples under the conditions studied. However, dynamic maceration produced an increase in TPI values in all the treatments, in contrast to traditional elaboration without maceration (data not shown), in despite of the short maceration times assayed. These results suggest that skin contact increases the phenolic contents in musts and wines equally. The similar TPI values in the control and the enzyme-treated musts could be explained by the fact that prefermentative maceration in the absence of ethanol results in the relatively low extraction of tannin compounds and flavan-3-ols (González-Manzano et al., 2004; Pinelo et al., 2006). Likewise, other authors have also found techniques least effective in extracting phenolic compounds from the pomace (Marais \& Rapp, 1988) or reported that the use of enzymes in maceration has not improved colour parameters or polyphenols compounds (Haight \& Gump, 1994; Fernandez-Zurbano et al., 1999; Bautista-Ortín et al., 2005; Alvarez et al., 2006). The TPI values found in the enzymatically macerated samples can be explained because high molecular weight polyphenols could be precipitated during the maceration process. The oxidisable polyphenols in the must can be polymerised and precipitated by chemical or enzymatic oxidation (Colagrande, 1999) by naturally occurring polyphenoloxidases from the musts. The increase of polyphenols and colour compounds in the resulting musts may be related principally to the dehydration levels of the grapes (Serratosa et al., 2008) and with time of maceration. As a result, the formation of brown pigment in musts from sun-dried Pedro Ximenez grapes during the drying process can be explained by the Maillard reaction between sugars and amino acids (Moreno et al., 2007). The extraction capacity of enzymes depends on the composition of the enzyme preparations and their activities, among other factors such as temperature or the

\section{TABLE 1}

Data of studied parameters and percentage differences $(\Delta)$ obtained from the analysis of the must samples before and after maceration treatment, mean \pm standard deviation $(S D)$. A different letter after the mean values within a row refers to significant differences at $P<0.05, n=4$.

\begin{tabular}{|c|c|c|c|c|c|c|c|}
\hline \multirow[t]{2}{*}{ Parameter } & \multicolumn{2}{|c|}{ Control } & \multicolumn{2}{|c|}{ Enzyme EM } & \multicolumn{2}{|c|}{ Enzyme VV } & \multirow[t]{2}{*}{ Significance } \\
\hline & Before & After & Before & After & Before & After & \\
\hline${ }^{\circ}$ Brix & $51.0 \pm 0.8$ & $52.0 \pm 0.8$ & $45.23 \pm 2.0$ & $48.15 \pm 1.9$ & $49.20 \pm 3.2$ & $52.3 \pm 3.8$ & \\
\hline$\Delta[\%]$ & \multicolumn{2}{|c|}{$2.01 \pm 0.71 \mathrm{a}$} & \multicolumn{2}{|c|}{$6.09 \pm 0.67 b$} & \multicolumn{2}{|c|}{$5.89 \pm 0.78 b$} & $P<0.001$ \\
\hline Titratable acidity $(\mathrm{g} / \mathrm{L})^{\mathrm{a}}$ & $5.21 \pm 0.2$ & $5.10 \pm 0.4$ & $4.39 \pm 0.3$ & $4.33 \pm 0.7$ & $4.97 \pm 0.5$ & $5.11 \pm 0.6$ & \\
\hline$\Delta[\%]$ & \multicolumn{2}{|c|}{$-2.33 \pm 6.76$} & \multicolumn{2}{|c|}{$-2.63 \pm 10.16$} & \multicolumn{2}{|c|}{$2.36 \pm 6.80$} & $\mathrm{~ns}^{\mathrm{f}}$ \\
\hline Volatile acidity $(\mathrm{g} / \mathrm{L})^{\mathrm{b}}$ & $0.33 \pm 0.03$ & $0.36 \pm 0.03$ & $0.32 \pm 0.02$ & $0.36 \pm 0.05$ & $0.31 \pm 0.05$ & $0.36 \pm 0.04$ & \\
\hline$\Delta[\%]$ & \multicolumn{2}{|c|}{$8.41 \pm 4.28$} & \multicolumn{2}{|c|}{$10.47 \pm 7.96$} & \multicolumn{2}{|c|}{$14.69 \pm 4.97$} & ns \\
\hline $\mathrm{EAN}(\mathrm{mg} / \mathrm{L})^{\mathrm{c}}$ & $535 \pm 35$ & $575 \pm 39$ & $444 \pm 55$ & $512 \pm 38$ & $508 \pm 70$ & $559 \pm 60$ & \\
\hline$\Delta[\%]$ & \multicolumn{2}{|c|}{$6.74 \pm 5.69$} & \multicolumn{2}{|c|}{$13.00 \pm 12.44$} & \multicolumn{2}{|c|}{$9.12 \pm 7.30$} & ns \\
\hline Reducing sugar (g/L) & $607 \pm 37$ & $647 \pm 38$ & $523 \pm 34$ & $581 \pm 15$ & $576 \pm 54$ & $621 \pm 55$ & \\
\hline$\Delta[\%]$ & \multicolumn{2}{|c|}{$6.07 \pm 3.47 \mathrm{a}$} & \multicolumn{2}{|c|}{$9.91 \pm 5.01 \mathrm{~b}$} & \multicolumn{2}{|c|}{$7.33 \pm 4.60 \mathrm{~b}$} & $P=0.012$ \\
\hline TPI (UA) ${ }^{\mathrm{d}}$ & $31.78 \pm 0.5$ & $51.88 \pm 3.3$ & $28.13 \pm 2.4$ & $43.65 \pm 10.3$ & $31.55 \pm 4.5$ & $54.68 \pm 7$ & \\
\hline$\Delta[\%]$ & \multicolumn{2}{|c|}{$38.56 \pm 3.95$} & \multicolumn{2}{|c|}{$33.74 \pm 10.87$} & \multicolumn{2}{|c|}{$42.35 \pm 1.75$} & ns \\
\hline Turbidity (UA) ${ }^{\mathrm{e}}$ & $0.22 \pm 0.03$ & $0.19 \pm 0.03$ & $0.13 \pm 0.06$ & $0.15 \pm 0.05$ & $0.19 \pm 0.03$ & $0.17 \pm 0.05$ & \\
\hline$\Delta[\%]$ & \multicolumn{2}{|c|}{$-11.33 \pm 10.29 \mathrm{ab}$} & \multicolumn{2}{|c|}{$12.90 \pm 6.76 \mathrm{~b}$} & \multicolumn{2}{|c|}{$-16.74 \pm 19.75 \mathrm{a}$} & $P=0.027$ \\
\hline
\end{tabular}

${ }^{a}$ Expressed as tartaric acid. ${ }^{\mathrm{b}}$ Expressed as acetic acid. ${ }^{\mathrm{c}}$ Easily assimilable nitrogen. ${ }^{\mathrm{d}}$ Total polyphenol index. ${ }^{\mathrm{e}}$ Turbidity is the absorbance values (AU) at 620 nm. ${ }^{\mathrm{f}}$ Not significant. 
conditions of the treatment. In red varieties, the colour extraction from skins is increased when the enzyme preparations have high cellulase and hemicellulase activities. Thus, the use of enzymes in red varieties increases the polyphenol content and mainly the anthocyanin content of the resulting wines (Sacchi et al., 2005; Kelebek et al., 2007; Romero-Cascales et al., 2007).

At the end of the maceration time, the total soluble solids as degrees Brix and the reducing sugar content of the enzyme-treated musts were higher than in the initial samples. The enzymatic musts had higher reducing sugars than the control. Enzymatic action makes the cell walls more permeable, which causes the extraction of soluble solid matter from the grape mash. The presence of polysaccharide-degrading enzymes (cellulolytic, hemicellulases and polygalacturonase activities) in the preparations contributes to enhancing the reducing sugars in the medium. The highest effect $(6.09 \pm 0.67 \%)$ was observed in the release of Brix when the enzyme EM was added. Previous works have shown that there are big increases in the amounts of arabinose, rhamnose, ribose, xylose and galactose after enzyme treatment (Noe et al., 1999).

With regard to turbidity, the enzyme EM increased the turbidity of the must samples, probably due to the higher activity of this enzyme; in contrast, the turbidity was diminished in the control and enzyme VV (polygalacturonase) treatments. Macerated enzyme treatments produce lower viscosity in musts due to the main activity of pectinase (Ough et al., 1975); the enzyme preparations also contain other side activities in different concentrations, such as pectin glycosidase, which can reduce or enhance this effect. The difference in turbidity of the samples was probably due to the development of the maceration process and the activities of the enzymes used. In previous works, changes in the turbidity of enzyme-treated musts were related to the cultivar or harvest studied (Lao et al., 1996).

The treatments also had a generally negative effect on the titratable acid content of the musts obtained in both the enzymatic and control samples. The dissolution of cations in the must caused by the maceration process possibly produced a reduction in titratable acidity by the neutralisation or salinisation of tartaric acid (Ribereau-Gayon et al., 2006). In contrast, the use of pectolytic enzymes in white Albillo musts showed an increase in titratable acidity (Pérez-Magariño \& González-San José, 2000).

The volatile acidity contents were similar in the enzyme-treated musts and in the control, thus were not affected by the enzymatic treatment of the musts, although a slight increase in the values was observed due to maceration. The increase in volatile acidity in the must is considered a negative effect in pre-fermentation treatments because of bacterial contamination. This depends largely on the initial health of the grapes, on the temperature of the must and on the oxygen available during maceration. The values of volatile acidity at the beginning and the end of the maceration step were typical $(\sim 0.35 \mathrm{~g} / \mathrm{L})$ for healthy grape harvests for this type of wine.

EAN estimates the quantity of assimilable nitrogen in juice, which includes nitrogen from $\mathrm{NH}_{4}^{+}$and the $\alpha$-amino acids, except proline. The EAN contents are important for the later alcoholic fermentation of the must. In these wines, fortification up to $9 \% \mathrm{v} / \mathrm{v}$ after pressing prevents alcoholic fermentation. In the traditional winemaking process, little or no fermentation occurs; therefore, this sweet wine is basically grape juice with alcoholic fortification. However, enzyme addition affected the EAN values in relation to the control samples; there was an increase in EAN after maceration of the samples, including the control. This observation is in agreement with previous works on the Chardonnay variety, which showed an increase in amino acids in macerated musts (Guitart et al., 1997).

The optimisation of the process in relation to time of maceration, temperature range, suitable enzyme preparations and doses is essentially to maximise the synergic effects and to obtain the desirable results; the preliminary trials were carried out in the

\section{TABLE 2}

Chemical composition of final sweet wines obtained (control and enzyme-treated wines); values are the mean \pm standard deviation $(S D)$. A different letter after the mean values within a row refers to significant differences at $P<0.05, n=4$.

\begin{tabular}{|c|c|c|c|c|}
\hline Parameter & Control sweet wines & EM sweet wines & VV sweet wines & Significance \\
\hline Alcoholic strength $(\% \mathrm{v} / \mathrm{v})$ & $9.03 \pm 0.1$ & $8.87 \pm 0.2$ & $8.91 \pm 0.1$ & $\mathrm{~ns}^{\mathrm{e}}$ \\
\hline${ }^{\circ}$ Brix & $40.00 \pm 0.3 \mathrm{a}$ & $42.27 \pm 0.9 \mathrm{~b}$ & $43.93 \pm 0.5 \mathrm{c}$ & $P=0.001$ \\
\hline Titratable acidity $(\mathrm{g} / \mathrm{L})^{\mathrm{a}}$ & $4.28 \pm 0.1 \mathrm{~b}$ & $3.84 \pm 0.1 \mathrm{a}$ & $4.15 \pm 0.2 \mathrm{ab}$ & $P=0.014$ \\
\hline $\mathrm{pH}$ & $4.38 \pm 0.1$ & $4.42 \pm 0.1$ & $4.35 \pm 0.1$ & ns \\
\hline Volatile acidity $(\mathrm{g} / \mathrm{L})^{\mathrm{b}}$ & $0.37 \pm 0.03$ & $0.34 \pm 0.02$ & $0.36 \pm 0.02$ & ns \\
\hline Reducing sugars (g/L) & $438.0 \pm 5.3 \mathrm{a}$ & $488.3 \pm 22.6 \mathrm{~b}$ & $515.7 \pm 9.3 \mathrm{~b}$ & $P=0.002$ \\
\hline $\mathrm{TPI}^{\mathrm{c}}$ & $29.70 \pm 2.0$ & $31.67 \pm 2.5$ & $31.33 \pm 3.5$ & ns \\
\hline Total polyphenol $(\mathrm{mg} / \mathrm{L})^{\mathrm{d}}$ & $1,052 \pm 42$ & $1,050 \pm 140$ & $1,047 \pm 72$ & ns \\
\hline Total iron (mg/L) & $14.97 \pm 0.1 \mathrm{~b}$ & $13.50 \pm 0.9 \mathrm{a}$ & $13.67 \pm 0.4 \mathrm{ab}$ & $P=0.035$ \\
\hline Iron(III) (mg/L) & $7.70 \pm 0.1 \mathrm{a}$ & $9.50 \pm 0.5 b$ & $10.53 \pm 0.7 b$ & $P=0.001$ \\
\hline Iron(II) (mg/L) & $7.27 \pm 0.1 \mathrm{~b}$ & $4.00 \pm 0.6 \mathrm{a}$ & $3.13 \pm 0.7 \mathrm{a}$ & $P<0.001$ \\
\hline
\end{tabular}

${ }^{a}$ Expressed as tartaric acid. ${ }^{\mathrm{b}}$ Expressed as acetic acid. ${ }^{\mathrm{c}} \mathrm{AU}$ at $280 \mathrm{~nm} .{ }^{\mathrm{d}}$ Expressed as $\mathrm{mg} / \mathrm{L}$ of gallic acid. ${ }^{\mathrm{e}}$ Not significant. 


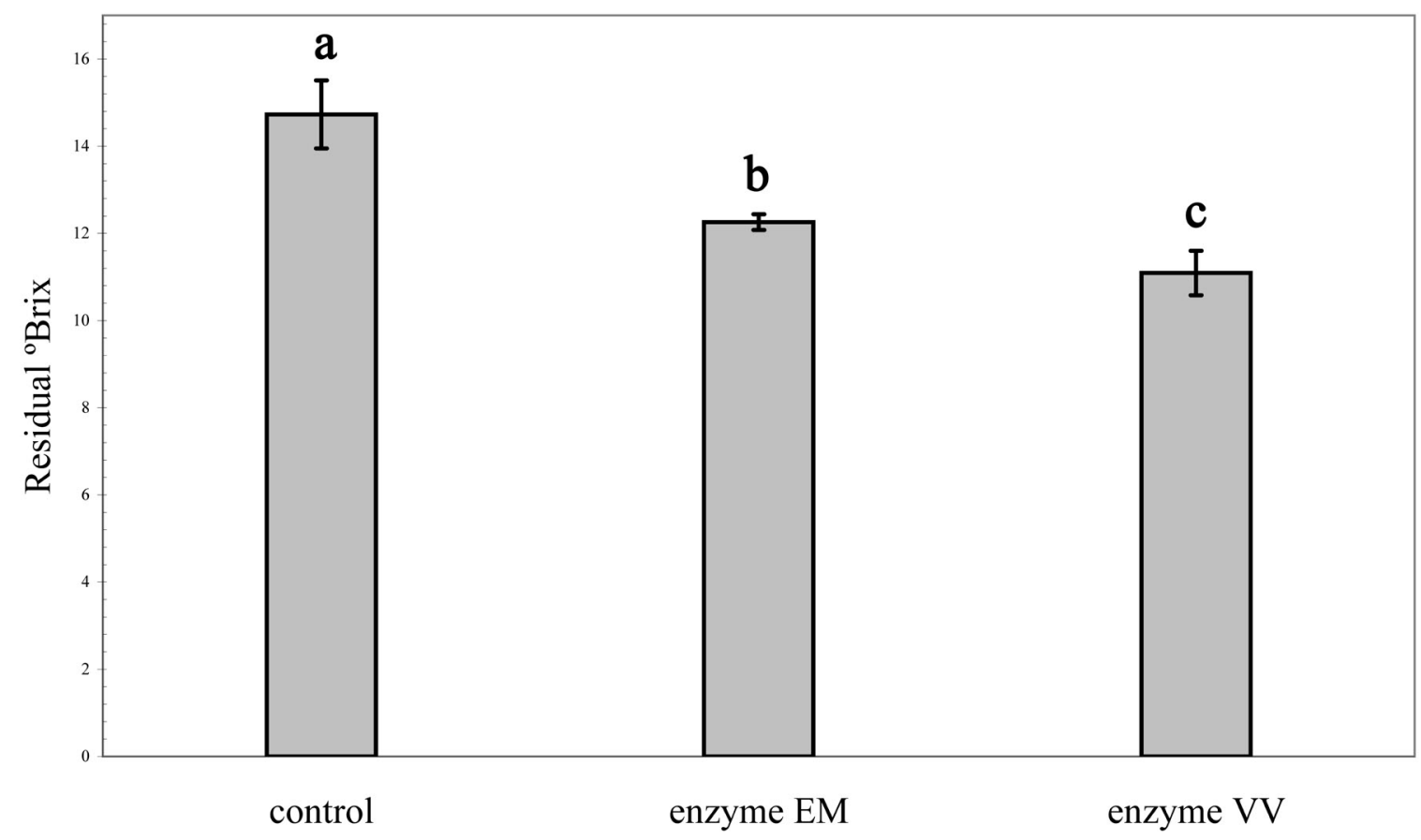

FIGURE 2

Residual degrees Brix of the pressed grape pomace from the control and enzyme-treated musts. Different letters between the column bars refer to significant differences at $P<0.05, n=4$.

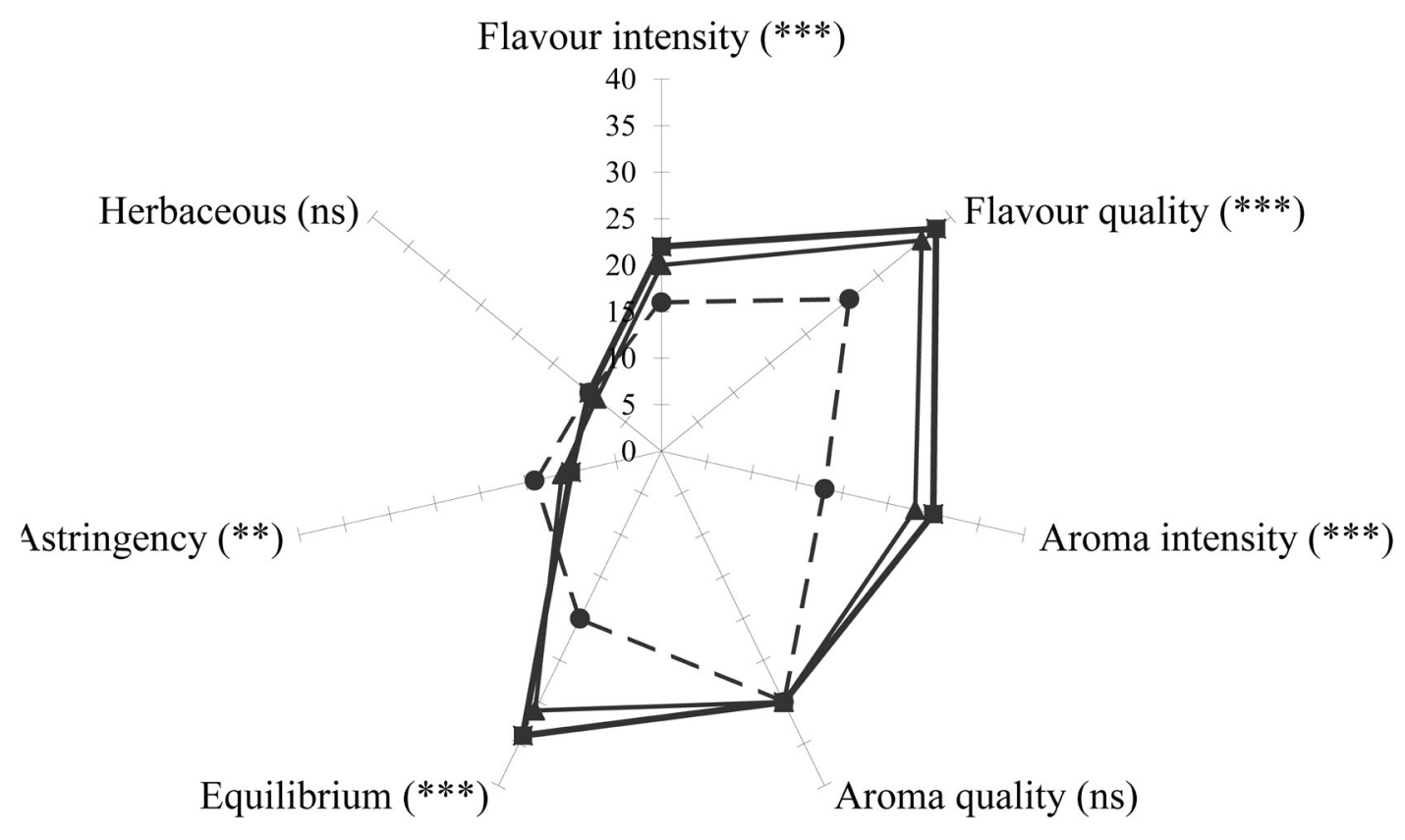

FIGURE 3

Comparative sensory scores of the control and enzyme-treated finished sweet wines. The asterisks indicate that the mean differs significantly at $P<0.01(* *)$ and 0.001 $(* * *)$

$\bullet$ Control wine --Enzyme EM - - -Enzyme VV. 


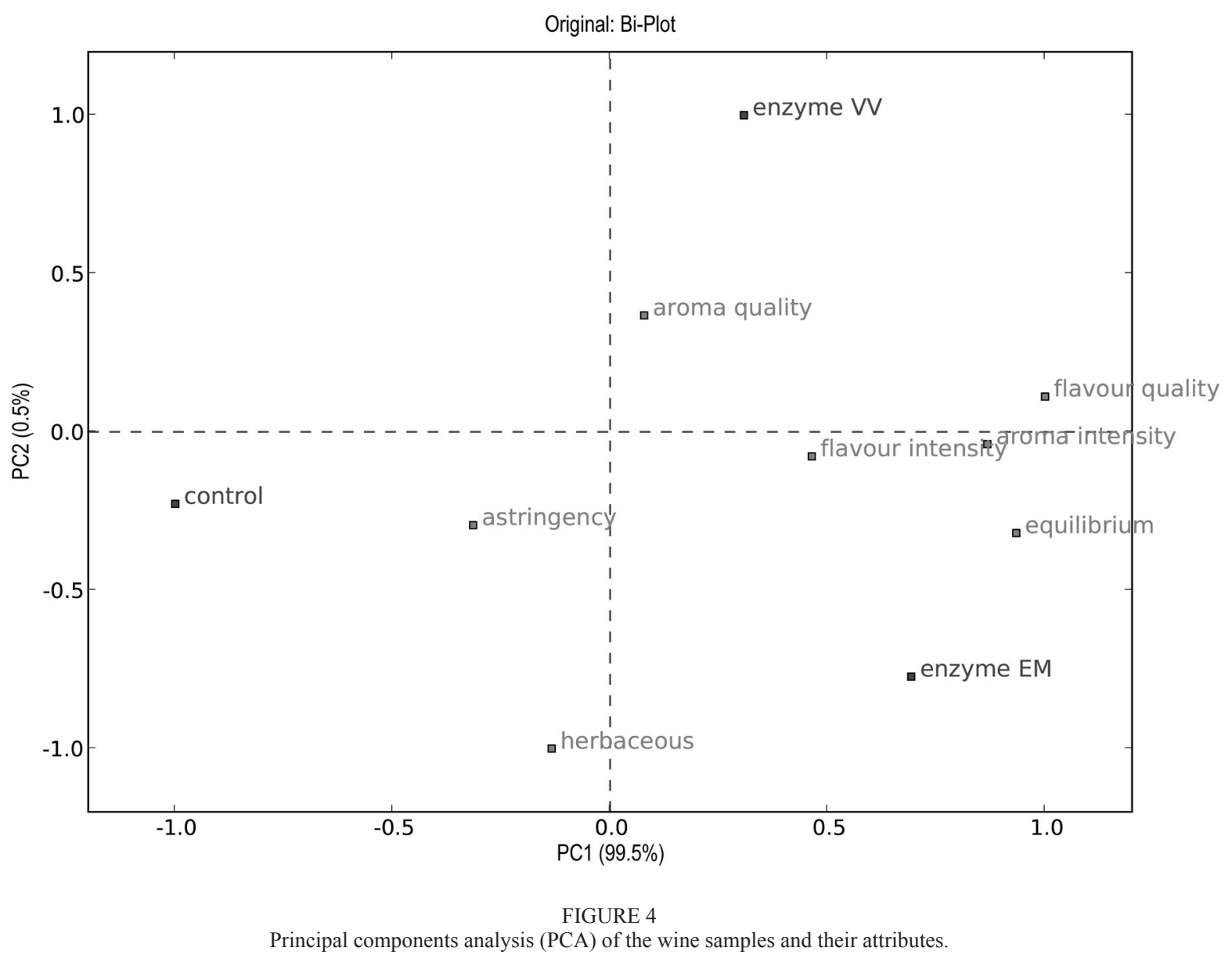

laboratory (results not shown). The temperature of the grape pomace and the duration of skin contact of the enzymes with the must are key factors that contribute to the correct development of the process. With regard to the reaction temperature, the performance of the pectinases probably was suboptimal taking into account that the temperature reaction was in the range 28 to $36^{\circ} \mathrm{C}$. The temperature of the must slows down or speeds up the maceration process with the enzymes. For cold maceration at temperatures of around $20^{\circ} \mathrm{C}$, the applied reaction time must be longer and higher enzyme dosages can be necessary. Nevertheless, reduced activities can be compensated for by higher dosages of enzymes or longer maceration times. With the aim of obtaining the maximum effect, additional experiments were carried out by increasing the dose of both the enzymes tested ( $3 \mathrm{~g}$ and $4 \mathrm{~g}$ per 100 $\mathrm{kg}$ of sun-dried grapes) and keeping the other parameters (room temperature and maceration time). The enzymatic liquefaction of the mash prevented the accurate recording of the data and the must samples could not be analysed. As a consequence, low enzyme dosages were sufficient for complete pectin degradation in these must samples. Low enzyme concentrations were used in the experiments. Much more significant effects may be observed on industrial scale. It is important to avoid an excess maceration time or enzyme quantity, which could involve complete liquefaction of the mash or pomace with pectin hydrolysis, and this could result in pressing problems. Another factor to consider, although it was not studied, would be the enzyme activity naturally present in these musts that could be increased by the maceration process adding up to the effect of the exogenous enzymes. Thus, taking this into account, the differences found between the control and enzyme-treated musts could be reduced. Nevertheless, to our knowledge, the endogenous enzyme potential and its activities in Pedro Ximenez musts before and after sun-drying process have not been studied.

\section{Effect of enzymes on sweet wines parameters}

Table 2 shows the analytical parameters of the final sweet wines obtained. In general, the chemical parameters of the wines produced from enzymatically macerated musts were very similar to those of the wines from control grapes without enzyme addition. All the wines had similar $\mathrm{pH}$ (around 4.38), volatile acidity, TPI and total polyphenols. While the degrees Brix and reducing sugars were enhanced due to the enzyme addition and maceration process, a decrease was observed in the titratable acidity of the wines. The reduction in titratable acidity in the macerated musts was due to tartaric acid neutralisation by the potassium liberated from the skins (Ribéreau-Gayon et al., 2006). Both enzymes showed a similar response, thus the analytical values of the final wines were similar. Kelebek (2007) had similar findings for dry red wine from the Öküzgözü variety, which showed no significant differences in density, ethanol, $\mathrm{pH}$, total acidity and reducing sugar, although slight differences were detected in volatile acidity.

The values for total iron varied according to the treatment utilised, thus the total iron in the enzymatic wines was lower (13.50 and $13.67 \mathrm{mg} / \mathrm{L})$ than in the control wines $(14.97 \mathrm{mg} / \mathrm{L})$. This could be due to the content of iron(III) in the enzyme-treated wines, which is responsible for the precipitation of colour compounds 

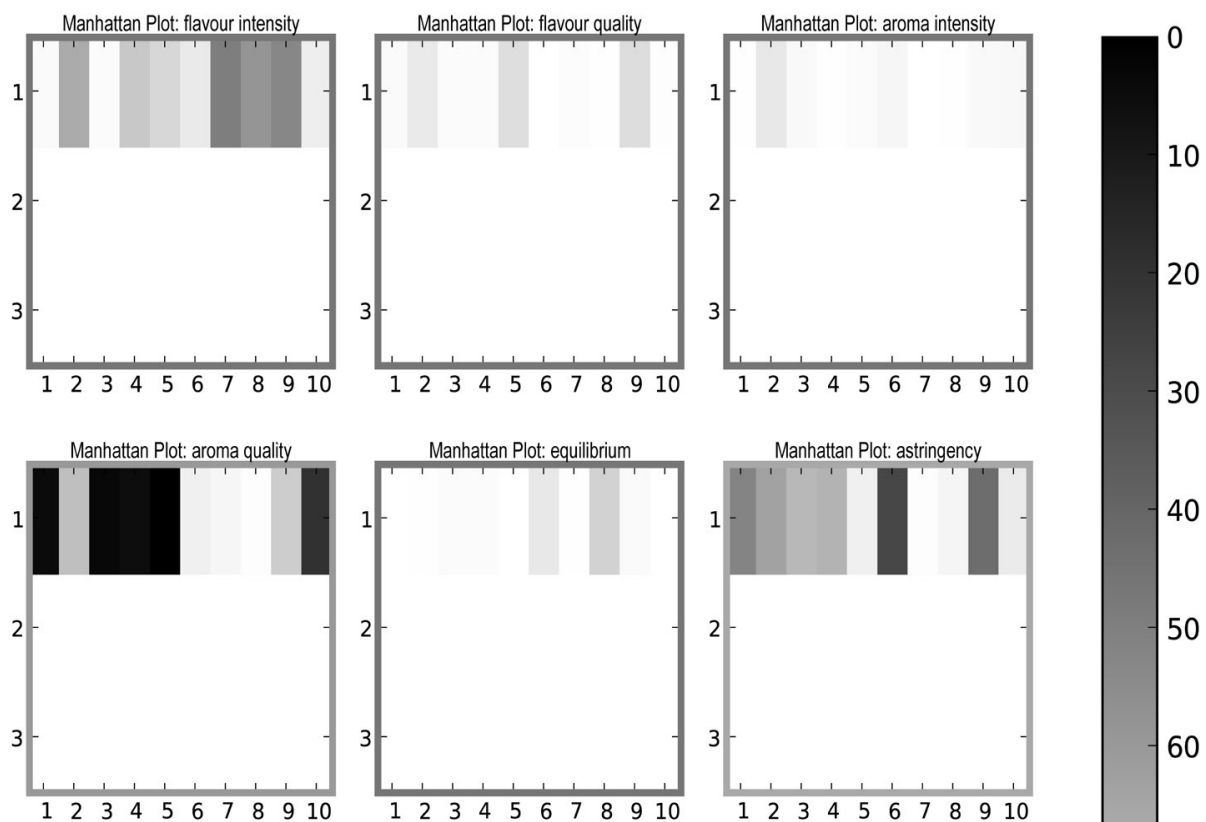

30
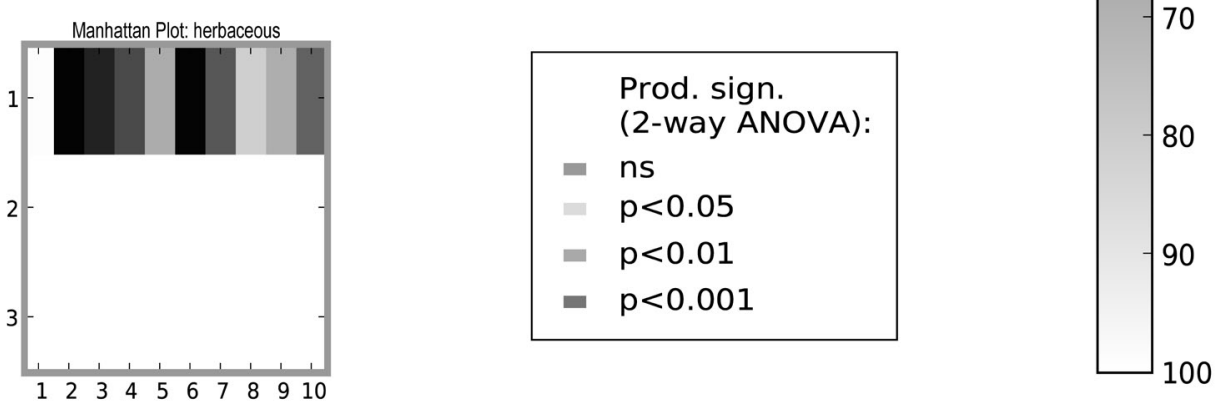

FIGURE 5

Manhattan plots of the attributes indicating variations from PCA on the data of individual assessors. Vertical axes represent the principal components and their cumulative variance. Horizontal axes represent the panel.

linked to metals such as iron. The enzyme-treated macerated musts were kept under oxidised conditions, at which the iron(II) may have been oxidized to iron(III) by dissolved oxygen. During maceration, process differences between the enzyme-treated musts and controls were more pronounced, while these analytical differences diminished in the wines that were obtained.

\section{Residual sugar content}

The data on the residual sugar content (expressed as degrees Brix) of the pressed pomace was used as a method for evaluating the extractability of the enzymes with regard to must sugar content (Fig. 2). The results revealed that the control samples were less leached than the pomace from the enzyme samples $(P<0.001)$ and between the two enzymes $(P=0.035)$. Despite the low dosage used, the use of enzymes has produced an improvement in the press capacity during grape processing and prevents extremely hard pressing to obtain a suitable must yield. The residual sugar of the pressed grape pomace confirms the positive effect on the volume of free-run must obtained. Similar findings have been reported previously (Ough \& Crowel, 1979; Van Oort \& CanalLlaubères, 2002). The residual sugar content of the pressed pomace was still important even when using enzymes, because of the high TSS concentration (between 43 and $52{ }^{\circ}$ Brix) of the initial sun-dried grapes used. Evidently, the degree of ripening and extractability of the skin cell walls of sun-dried grapes, in combination with the processing methods used, will influence the quality and final characteristics of the resulting wines. Therefore, enzyme addition can have advantageous results in the making of these very sweet wines because it produces an improvement in the effective use of the equipment, and a reduction in the time necessary for processing and in the loss of must. In addition, the use of various enzyme preparations together with different activities in the treatment of the must can produce synergistic additional effects to optimise the use of these products.

\section{Sensory analyses}

As a first step, the preliminary results of the triangle tests (results not shown) demonstrate that there was a statistically significant difference $(P<0.01)$, indicating that the control wines could be distinguished from the enzyme-treated wines. In order to determine the magnitude of the difference between the samples, the panel performed a descriptive sensorial analysis. To this end, the sensory attributes evaluated were: astringency and herbaceous notes, general equilibrium, flavour and aroma (quality and intensity) of the samples. The principal differences between the sensory profiles of the three sweet wines are presented in Fig. 3. These results 
indicate that the enzymes increased aroma compounds and the general quality impression of these sweet wines. The sensory tests indicate that the quality of the sweet wine is improved when these enzymes are used. Therefore, the flavour intensity and quality, aroma intensity and general equilibrium of the enzyme-treated sweet wines showed significant differences against the control $(P$ $<0.001)$. All the wines were evaluated in the same way regarding aroma quality, showing no significant defects. The wines made with enzymes were the highest rated on aroma intensity, partly because the typical aromas that predominated were more intense. The sweet wines elaborated with enzyme EM were punctuated better in the sensorial trials. The general sensorial characteristics that dominated corresponded to the peculiarities of these sweet wines when they are young, mostly grape-based aromas with notes of raisins, figs, dates and honey, caramel or toffee. Astringency and herbaceous characters are considered defects in these types of sweet wines that develop due to excessive yields from the pressing process and from the use of non-ripe grapes with high concentrations of C-6 compounds.

Fig. 4 provides a graphic illustration of the principal components analysis (PCA) of the samples and their studied attributes. As can be seen, PC1 explains $99.5 \%$ of the variance, while PC2 explains $0.5 \%$. The three types of wines are identified according to their score attributes and by showing how the attributes contributed to the variation in the sensory data. This confirms what was shown in the spider plot (Fig. 3).

The information about the performance of the assessors, which can be provided by PanelCheck program (Tomic et al., 2010), is show in Fig. 5. The Manhattan plots show the variation for one attribute across all assessors. Therefore, every one of the assessors had an explained variance of close to $99 \%$ for all the significant attributes with PC1, except with regard to flavour intensity, which shows great variability among the assessors. It also shows the assessors' performance in the non-significant attributes "aroma quality" and "herbaceous".

The cellulolytic and hemicellulolytic secondary activities may contribute to the release of bound aroma precursors from the skins and pulp of dried grapes (Van Oort \& Canal-Llaubères, 2002). In addition, the residual glycosidic activity in the enzymes probably liberates the aroma compounds in the resulting musts during maceration; this effect could be higher if the $\beta$-glucosidase from the enzyme preparations was not inhibited by glucose (Maicas $\&$ Mateo, 2005). The $\beta$-glucosidase action and its efficacy depends on various factors, such as the origin of the enzymes, the concentration of glucose and ethanol and the $\mathrm{pH}$ of the medium. In most cases, the $\mathrm{pH}$ values of the sun-dried musts were near to the activity optimum, with a $\mathrm{pH}$ range between 4.5 and 6.0 (Acuna-Arguelles et al., 1995).

\section{CONCLUSIONS}

In summary, the enzyme preparations assayed, combined with dynamic maceration, increased the degrees Brix of the musts obtained, while at the same time improving the total juice yield in the industrial scale experiments. In contrast, these enzyme preparations did not affect the TPI values of the resulting musts and wines significantly. With regard to the effect of the enzymes on the sensory properties, the sweet wines obtained with the enzyme treatments were appreciated more in the sensory evaluations.
Therefore, a more detailed study of the enzyme activities of commercial preparations will be of great interest to understand their influence on sensory findings, and to study the impact of new aromatic compounds formed and their contribution to wine aroma and flavour profiles. This technique, pre-fermentative enzyme addition together with short dynamic maceration under controlled conditions, appears to be interesting for the production of fortified sweet wines made with sun-dried grapes, particularly from the Pedro Ximenez variety.

\section{LITERATURE CITED}

Acuña-Argüelles, M.E., Gutierrez-Rojas, M., Viniegra-Gonzalez, G. \& FavelaToress, E., 1995. Production and properties of three pectinolytic activities produced by $A$. niger in submerged and solid state fermentation. Appl. Microbiol. Biotechnol. 43, 808-814.

Alvarez, I., Aleixandre, J.L., Garcia, M.J. \& Lizama, V., 2006. Impact of prefermentative maceration on the phenolic and volatile compounds in Monastrell red wines. Anal. Chim. Acta. 563, 109-115.

Ayestarán, B., Guadalupe, Z. \& León, D., 2004. Quantification of major grape polysaccharide (Tempranillo v.) released by maceration enzymes during the fermentation process. Anal. Chim. Acta. 513, 29-39.

Bautista-Ortín, A.B., Martínez-Cutillas, A., Ros-García, J.M., López-Roca, J.M. \& Gómez-Plaza, E., 2005. Improving colour extraction and stability in red wines: the use of maceration enzymes and enological tannins. Int. J. Food Sci. Technol. 40, 867-878.

Cabaroglu, T., Selli, S., Canbas, A., Lepoutre, J.P. \& Günata, Z., 2003. Wine flavor enhancement through the use of exogenous fungal glycosidases. Enzyme Microb. Technol. 33, 581-587.

Canal-Llauberes, R.M., 1990. Utilisation des enzymes dans les procédés d'extraction en œnologie. Rev. Franc. Oenol. 122, 28-33.

Castro-Vázquez, I., Pérez-Coello, M.S. \& Cabezudo, M.D., 2002. Effects of enzyme treatment and skin extraction on varietal volatiles in Spanish wines made from Chardonnay, Muscat, Airén, and Macabeo grapes. Anal. Chim. Acta. 458, 39-44.

Colagrande, O., 1999. Wine production. In: Flickinger, M.C. \& Drew, S.W. (eds). The Encyclopedia of Bioprocess Technology: Fermentation, Biocatalysis and Bioseparation. John Wiley and Sons, New York. pp. 2677-2693.

Commission Regulation EC 1331/08 of 16 December 2008 establishing a common authorisation procedure for food additives, food enzymes and food flavourings. Off. J. Eur. Comm. L354, 1-16.

Commission Regulation EC 1332/08 of 16 December 2008 on food enzymes. Off. J. Eur. Comm. L354, 7-15.

Commission Regulation EC 2676/90 of 17 September 1990, determining Community methods for the analysis of wines. Off. J. Eur. Comm. L272, 1-192.

Commission Regulation EC 606/09 of 10 July 2009, laying down detailed rules for implementing Council Regulation (EC) No 479/2008 as regards the categories of grapevine products, oenological practices and the applicable restrictions. Off. J. Eur. Comm. L193, 1-59.

Cruess, W.V., O’Neal, R., Chong, G. \& Uchimoto, D., 1951. The effect of pectic enzymes in wine making. Am. J. Enol. Vitic. 2, 59-75.

Doco, T., Williams, P. \& Cheynier, V., 2007. Effect of flash release and pectinolytic enzyme treatments on wine polysaccharide composition. J. Agric. Food Chem. 55, 6643-6649.

Ducruet, J., Canal-Llauberes, R.M. \& Glories, Y., 1997. Influence des enzymes pectolytiques sélectionnnés pour l'œnologie sur la qualité et la composition des vins rouges. Rev. Franc. Oenol. 166, 16-19.

Fernandez-Zurbano, P., Ferreira, V., Pena, C., Escudero, A. \& Cacho, J., 1999. Effects of maceration time and pectolytic enzymes added during maceration on the phenolic composition of must. Food Sci. Technol. Int. 5, 319-325.

Franco, M., Peinado, R.A., Medina, M. \& Moreno, J., 2004. Off-vine grape drying effect on volatile compounds and aromatic series in must from Pedro Ximénez grape variety. J. Agric. Food Chem. 52, 3905-3910. 
Ganga, A., Piñaga, F., Querol, A., Vallés, S. \& Ramon, D., 2001. Cell-wall degrading enzymes in the release of grape aroma precursors. Food Sci. Technol. Int. 7, 83-87.

Giannessi, P. \& Matta, M., 1978. Trattato di Scienza e Technica Enologica, vol I. Analisi e controllo dei mosti e dei vini. Editorial AEB, Brescia. pp. 87-88.

González-Manzano, S., Rivas-Gonzalo, J.C. \& Santos-Buelga, C., 2004. Extraction of flavan-3-ols from grape seed and skin into wine using simulated maceration. Anal. Chim. Acta. 513, 283-289.

Guérin, L., Sutter, D.H., Demois, A., Chereau, M. \& Trandafir, G., 2009. Determination of activity profiles of the main commercial enzyme preparations used in winemaking. Am. J. Enol. Vitic. 60, 322-331.

Guitart, A., Hernández-Orte, P. \& Cacho, J., 1997. Effects of maceration on the amino acid content of Chardonnay musts and wines. Vitis 36, 43-47.

Haight, K.G. \& Gump, B.H., 1994. The use of macerating enzymes in grape juice processing. Am. J. Enol. Vitic. 45, 113-116.

Hernanz, D., Recamales, A.F., González-Miret, M.L., Gómez-Míguez, M.J., Vicario, I.M. \& Heredia, F.J., 2007. Phenolic composition of white wines with a prefermentative maceration at experimental and industrial scale. J. Food Eng. $80,327-335$.

ISO (International Organisation for Standardisation), 2004. Sensory analysis. Methodology. triangle test, ISO 4120. ISO, Geneva.

Kashyap, D.R., Vohra, P.K., Chopra, S. \& Tewari, R., 2001. Applications of pectinases in the commercial sector: a review. Bioresour. Technol. 77, 215-227.

Katalinić, V., Možina, S.S., Skroza, D., Generalić, I., Abramovič, H., Miloš, M., Ljubenkov, I., Piskernik, S., Pezo, I., Terpinc, P. \& Boban, M., 2010. Antioxidative and vasodilatory effects of phenolic acids in wine. Food Chem. 119, 715-723.

Kelebek, H., Canbas, A., Cabaroglu, T. \& Selli, S., 2007. Improvement of anthocyanin content in the cv. Öküzgözü wines by using pectolytic enzymes. Food Chem. 105, 334-339.

Lao, C., Lopez-Tamames, E., Buxaderas, S. \& De la Torre-Boronat, M.C., 1996. Grape pectic enzyme treatment effect on white musts and wines composition. J. Food Sci. 61, 553-556.

Maicas, S. \& Mateo, J.J., 2005. Hydrolysis of terpenyl glycosides in grape juice and other fruit juices: a review. Appl. Microbiol. Biotechnol. 67, 322-335.

Marais, J. \& Rapp, A., 1988. Effects of skin-contact time and temperature on juice and wine composition and wine quality. S. Afr. J. Enol. Vitic. 9, 22-30.

Márquez, R., Castro, R., Natera, R. \& García-Barroso, C., 2008. Characterisation of the volatile fraction of Andalusian sweet wines. Eur. Food Res. Technol. 226, $1479-1484$

Mateo, J.J. \& Jiménez, M., 2000. Monoterpenes in grape juice and wines. J. Chromat. A 881, 557-567.

Moreno, J., Peinado, J. \& Peinado, R.A., 2007. Antioxidant activity of musts from Pedro Ximénez grapes subjected to off-vine drying process. Food Chem. 104, 224-228.

Noe, C.R., Lachmann, B., Möllenbeck, S. \& Richter, P., 1999. Determination of reducing sugars in selected beverages by capillary electrophoresis. Z. Lebensm. Unters. Forsch. A. 208, 148-152.

OIV (International Organisation of the Vine and Wine), 2009. Resolution OIV/ OENO 365/2009. Available: http://news.reseau-concept.net/images/oiv uk/ Client/OIV-Oeno_365-2009_EN.pdf (Accessed 3 February 2010).

OIV (International Organisation of Vine and Wine), 1994. Normes des concours internationaux des vins. Bulletin L'OIV 67, 558-597.

Ough, C.S. \& Crowel, E.A., 1979. Pectic enzyme treatments of white grapes: temperature variety skin-contact time factors. Am. J. Enol. Vitic. 30, 22-27.
Ough, C.S., Noble, A.C. \& Temple, D., 1975. Pectic enzymes effects on red grapes. Am. J. Enol. Vitic. 26, 195-200.

Pardo, F., Salinas, M.R., Alonso, G.L., Navarro, G. \& Huerta, M.D., 1999. Effect of diverse enzyme preparations on the extraction and evolution of phenolic compounds in red wines. Food Chem. 67, 135-142.

Parker, T.L., Wang, X.H., Pazmiño, J. \& Engeseth, N.J., 2007. Antioxidant capacity and phenolic content of grapes, sun-dried raisins, and golden raisins and their effect on ex vivo serum antioxidant capacity. J. Agric. Food Chem. 55, 84728477

Pérez-Magariño, S. \& González-San José, M.L., 2000. Effect of pectolytic enzymes on the composition of white grape musts and wines. Ital. J. Food Sci. $12,153-162$.

Pimenta-Braz, P.N., Ricardo-da-Silva, J.M. \& Laureano, O., 1998. Evaluation of pectolytic activities of enological interest in industrial enzyme preparations. Z. Lebensm. Unters. Forsch. A 206, 14-20.

Pinelo, M., Arnous, A. \& Meyer, A.S., 2006. Upgrading of grape skins: significance of plant cell-wall structural components and extraction techniques for phenol release. Trends Food Sci. Technol. 17, 579-590.

Revilla, I. \& González-San José, M.L., 2003. Compositional changes during the storage of red wines treated with pectolytic enzymes: low molecular-weight phenols and flavan-3-ol derivative levels. Food Chem. 80, 205-214.

Ribéreau-Gayon, P., Glories, Y., Maujean, A. \& Dubourdieu, D., 2006. Handbook of enology, vol. I. John Wiley and Sons, England.

Romero-Cascales, I., Fernández-Fernández, J.I., Ros-García, J.M., López-Roca, J.M. \& Gómez-Plaza, E., 2007. Characterisation of the main enzymatic activities present in six commercial macerating enzymes and their effects on extracting colour during winemaking of Monastrell grapes. Int. J. Food Sci. Technol. 43, 1295-1305.

Sacchi, K., Bisson, L.F. \& Adams, D.O., 2005. A review of the effect of winemaking techniques on phenolic extraction in red wines. Am. J. Enol. Vitic. 56, 197-206.

Salinas, M.R., Garijo, J., Pardo, F., Zalacain, A. \& Alonso, G.L., 2003. Color, polyphenol, and aroma compounds in rosé wines after prefermentative maceration and enzymatic treatments. Am. J. Enol. Vitic. 54, 195-202.

Sánchez Palomo, E., Pérez-Coello, M.S., Díaz-Maroto, M.C., González Viñas, M.A. \& Cabezudo, M.D., 2006. Contribution of free and glycosidically-bound volatile compounds to the aroma of muscat "a petit grains" wines and effect of skin contact. Food Chem. 95, 279-289.

Selli, S., Cabaroglu, T., Canbas, A., Erten, H. \& Nurgel, C., 2003. Effect of skin contact on the aroma composition of the musts of Vitis vinifera L. cv. Muscat of Bornova and Narince grown in Turkey. Food Chem. 81, 341-347.

Serratosa, M.P., Lopez-Toledano, A., Merida, J. \& Medina, M., 2008. Changes in color and phenolic compounds during the raisining of grape cv. Pedro Ximenez. J. Agric. Food Chem. 56, 2810-2816.

Singleton, V.L. \& Rossi, J.A., 1965. Colorimetry of total phenolic with phosphomolybdic-phosphotungstic acid reagents. Am. J. Enol. Vitic. 16, 144158 .

Stone, H. \& Sidel, J.L., 2004 (3rd ed). Sensory evaluation practices. Elsevier, San Diego.

Tomic, O., Luciano, G., Nilsen, A., Hyldig, G., Lorensesn, K. \& Næs, T., 2010. Analysing sensory panel performance in a proficiency test using the PanelCheck software. Eur. Food Res. Technol. 230, 497-511.

Van Oort, M. \& Canal-Llaubères, R.M., 2002. Enzymes in wine production. In: Whitehurst, R.J. \& Law, B.A. (eds). Enzymes in food technology. Sheffield Academic Press, UK. pp. 76-89. 